\title{
GROWTH AND YIELD RESPONSE OF FLAX (LINUM USITATISSIMUM L.) TO DIFFERENT RATES OF CHARCOAL AND POTASSIUM FERTILIZER IN ERBIL, KURDISTAN REGION-IRAQ
}

\author{
Rabar Fatah Salih, Garilla Anwar Osman and Lawest Hamed AZiz \\ Dept. of Field Crops, College of Agricultural Engineering Sciences, University of Salahaddin, \\ Kurdistan Region- Iraq
}

(Received: July 16, 2019; Accepted for Publication: December 3,2019)

\begin{abstract}
This study investigate the influence of different levels of charcoal and inorganic fertilizer on the some growth and yield parameters of flax crop. The study conducted in Grdarasha Field which is belong to the College of Agricultural Engineering Sciences, Salahaddin University - Erbil in the 2017 - 2018 growing season. Charcoal has not been yet applied as a fertilizer in flax field and any crops in Kurdistan, therefore its potential effect has been investigated for the first time in this study. Interaction among charcoal and potassium at the rate of $\left(800 \mathrm{~g} / \mathrm{m}^{2}\right.$ and $\left.60 \mathrm{~kg} / \mathrm{ha}\right)$, respectively were caused to significantly improve some growth and yield parameters such as plant height, technical stem length, total fresh yield and dry stem yield by the about $(63.4 \mathrm{~cm}, 46.3 \mathrm{~cm}, 11.5 \mathrm{t} / \mathrm{ha}$ and $3.5 \mathrm{t} / \mathrm{ha})$, respectively. Additionally, potassium alone especially at the rate of $60 \mathrm{~kg} / \mathrm{ha}$ showed an impact role to provide high value of both growth and yieldstudied characteristics. On the bright of the results, an opportunity could be seen to do more researches in the future about the effects of charcoal and inorganic fertilizers not only on flax but also on other crops.
\end{abstract}

KEYWORDS: Flax. Charcoal. Potassium fertilizer. Kurdistan https://doi.org/10.26682/ajuod.2019.22.2.7

\section{INTRODUCTION}

F lax is one ofthe trade and industral crop which plays an important role in regional policy through its local fabrication as well as exportation (Khalifa et al., 2011). Nevertheless, it is one of the most important medicinal plants; therefore, human consumption of the flax is increasing rapidly for food and industry (Khourang et al., 2012). Additionally, which is a multipurpose crop that can be growing for extraction oil from its seeds and fiber from stems (Martin et al., 2006). Other products substitute for linseed oil in paints. The health benefits of flaxseedsincreased market value for the crop.

Charcoal increases nutrient contents and nutrient retention capacity of the soil,which was improved nutrient supply for plants and reduced nutrient losses by leaching (Glaser et al., 2002). Oguntunde et al.(2004) reported that the nutrient availability increased due to charcoal residues in the kiln sites.Charcoal addingto the soilestablished to sustain fertility if an extra nutrient source is provided. In comparison with soil fertilized by a mineral nutrients, the soil fertilized with charcoal the releasingand availability of (P, K, Ca, Mg, and $\mathrm{N})$ did not reduced (Steiner et al., 2007). Application of charcoal and different levels of nitrogen affected significantly of chemical and physical properties of soil in one side and growth and yield parameters of kenaf in other side (Malisa et al., 2011). Three different grain sizes of charcoal were added to the soil to reduce nutrient leaching from the soil and to improve plant growth (Kingshuk et al., 2012). Gale et al. (2017) reported that plants in biochar treatments flowered earlier and produce more biomass overall.

Potassium has an important role in the growth of plants. Different levels of potassium fertilizer were apllaied to two varieties of kenaf FH-952 and 4383 that planted in 2013 at Universiti Putra Malaysia (UPM). Growth and yield parameters were improved by adding potassium especially at the rate of $150 \mathrm{~kg} / \mathrm{ha}$ (Salih et al., 2014a). Additionally, potassium has probable cause in an increasing the amount of crop yield and improving the quality of plants. Further, it improves nitrogen use efficiency which is directly linked to production of cellulose and 
protein content in the cell wall of the plant fibers (Salih, 2015).

\section{MATERIALS AND METHODS}

The study was carried out in Gardarasha Field, College of Agricultural Engineering Sciences, Salahaddin University - Erbil. Local charcoal was selected as a first factor in different levels $\left(0,250\right.$ and $\left.800 \mathrm{~g} / \mathrm{m}^{2}\right)$, and inorganic fertilizer potassium $\mathrm{KCl}$ was applied as the second factor at the rates of $(0,60$ and 140 $\mathrm{kg} / \mathrm{ha}$ ) giving a total 27 treatments. The experimental design used was Factorial Randomized Complete Block Design (RCBD). Twenty seven treatments weretested in three replications.Each treatment was applied on $1 \mathrm{~m}^{2}$ plots $(1 \mathrm{~m} \times 1 \mathrm{~m})$ (Figure 1$)$. The variety of flaxused was Thorshansity 72, Poland cultivar, sowing was done manually on $1^{\text {st }}$ December 2017. Seeds were planted in row, each plot consisted of 8 rows, the space between the rows was $8 \mathrm{~cm}$, and the seed rate was $8 \mathrm{~g} / \mathrm{m}^{2}$. Charcoal was mixed with soil of the surface layer of each plots at the same day of the sowing, while potassium was added on 15 January 2018. Seeds were germinated after 13 days of planting, on 8 January 2018 thinning was done. Plots were irrigated 18 times. Weeding control were done manually which was nearly 8 times. Table 1 shows the meaning of treatments abbreviations.

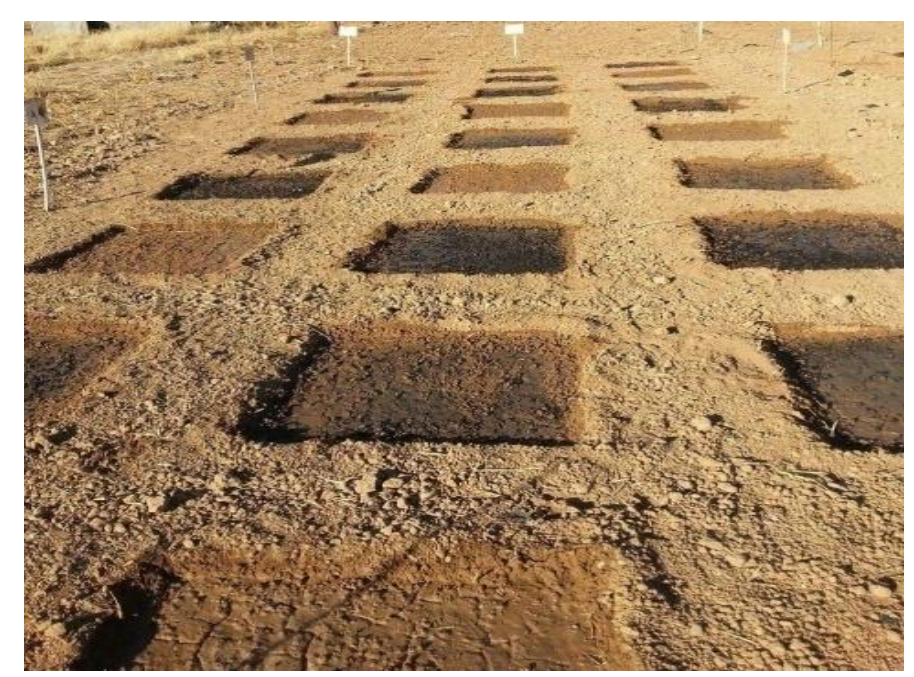

Fig. (1): Field experimental design.

Table (1). Meaning of abbreviations

\begin{tabular}{ll}
\hline Abbreviations & Meaning \\
\hline C0K0 & $\begin{array}{l}\text { Charcoal zero } \\
\text { zerokg/ha(control) }\end{array}$ \\
\hline C0K60 & Charcoal zero g/m $/ \mathrm{m}^{2}$, potassium $60 \mathrm{~kg} / \mathrm{ha}$ \\
\hline C0K140 & Charcoal zero $\mathrm{g} / \mathrm{m}^{2}$, potassium $140 \mathrm{~kg} / \mathrm{ha}$ \\
\hline C250K0 & Charcoal $250 \mathrm{~g} / \mathrm{m}^{2}$, potassium zero kg/ha \\
\hline C250K60 & Charcoal $250 \mathrm{~g} / \mathrm{m}^{2}$, potassium $60 \mathrm{~kg} / \mathrm{ha}$ \\
\hline C250K140 & Charcoal $250 \mathrm{~g} / \mathrm{m}^{2}$, potassium $140 \mathrm{~kg} / \mathrm{ha}$ \\
\hline C800K0 & Charcoal $800 \mathrm{~g} / \mathrm{m}^{2}$, potassium zero kg/ha \\
\hline C800K60 & Charcoal $800 \mathrm{~g} / \mathrm{m}^{2}$, potassium $60 \mathrm{~kg} / \mathrm{ha}$ \\
\hline C800K140 & Charcoal $800 \mathrm{~g} / \mathrm{m}^{2}$, potassium $140 \mathrm{~kg} / \mathrm{ha}$ \\
\hline
\end{tabular}




\section{Data collection}

Ten plant samples at full maturity stage were selected from each experimental unit to estimate the following characteristics:

1. Plant height $(\mathrm{cm})$.

2. Technical stem length $(\mathrm{cm})$.

3. Number of fruit branches/plant.

4. Number of capsules/plant.

5. Number of seeds/capsule.

6. Stem diameter $(\mathrm{mm})$.

Plants were also harvested from the whole plots to determine some parameters in relation to yield such as:
1. Total fresh yield (t/ha).

2. Dry stem yield (t/ha).

3.

\section{RESULTS AND DISCUSSIONS}

Based on ANOVA (Table 2) and figures $(2,3,4,5,6,7,8$ and 9) there were highly significant effect $(\mathrm{p}=0.05)$ of different levels of charcoal, potassium and interaction between them on some growth and yield parameters.

Table (2). The analysis of variance (ANOVA) for the effect of different levels of charcoal and potassium on growth and yield parameters

\begin{tabular}{|c|c|c|c|c|c|c|c|c|c|}
\hline Source of Variation & ${ }^{\star} \mathrm{DF}$ & $\mathrm{PH}$ & $\overline{T S L}$ & NFB/P & NC/P & NS/C & SD & TFY & DSY \\
\hline & & \multicolumn{8}{|c|}{ Mean Square } \\
\hline Charcoal & 2 & 4.15 & 17.71 & 0.06 & 9.41 & 0.07 & 0.02 & 0.34 & 0.18 \\
\hline Potassium & 2 & 70.14 & 14.28 & 0.01 & 2.18 & 0.15 & 0.01 & 4.07 & 1.23 \\
\hline \multirow[t]{2}{*}{ Charcoal $\times$ Potassium } & 4 & 21.14 & 24.01 & 0.42 & 1.66 & 0.16 & 0.01 & 1.90 & 0.47 \\
\hline & & \multicolumn{8}{|c|}{ F. value } \\
\hline Charcoal & 2 & 3.47 & 27.85 & 2.47 & 113.98 & 0.87 & 5.33 & 0.65 & 1.60 \\
\hline Potassium & 2 & 58.77 & 22.46 & 0.27 & 26.40 & 1.99 & 3.00 & 7.72 & 11.20 \\
\hline \multirow[t]{2}{*}{ Charcoal $\times$ Potassium } & 4 & 17.72 & 37.75 & 16.32 & 20.06 & 2.00 & 2.33 & 3.60 & 4.25 \\
\hline & & \multicolumn{8}{|c|}{ P. value } \\
\hline Charcoal & 2 & 0.06 & 0.00 & 0.12 & 0.00 & 0.44 & 0.02 & 0.54 & 0.23 \\
\hline Potassium & 2 & 0.00 & 0.00 & 0.77 & 0.00 & 0.17 & 0.08 & 0.01 & 0.00 \\
\hline Charcoal $\times$ Potassium & 4 & 0.00 & 0.00 & 0.00 & 0.00 & 0.14 & 0.10 & 0.03 & 0.02 \\
\hline
\end{tabular}

* Significant occurs when P.value $\leq 0.05$.

$\mathrm{DF}=$ Degree of Freedom. PH=Plant Height, TSL=Technical Stem Length, NFB/P=Number of Fruit Branches/Plant, NC/P=Number of Capsules/Plant, NS/C=Number of Seeds/Capsule, SD=Stem Diameter, TFY=Total Fresh Yield, DSY=Dry Stem Yield

Plant height was increased dramatically with the addition of charcoal and potassium at the rate of $\left(800 \mathrm{~g} / \mathrm{m}^{2}\right.$ and $\left.60 \mathrm{~kg} / \mathrm{ha}\right)$, respectively which was $63.4 \mathrm{~cm}$ (Figure 2). This change might be due to effect of potassium of cell wall deviation(Salih et al., 2014b), since at the control treatment without charcoal and potassium the plant height was only $58.9 \mathrm{~cm}$ but with adding potassium at the rate of $60 \mathrm{~kg} / \mathrm{ha}$ plant height improved to $(60.5 \mathrm{~cm})$. Also,it could be directly relationship to biochar affecting by improving soil quality (Bakry et al., 2014). Gale et al. (2017) was also showed the importance of biochar or charcoal on plant growth. However, the impact of different levels of charcoal and nitrogen fertilizer on kenaf plant were found by (Malisa et al., 


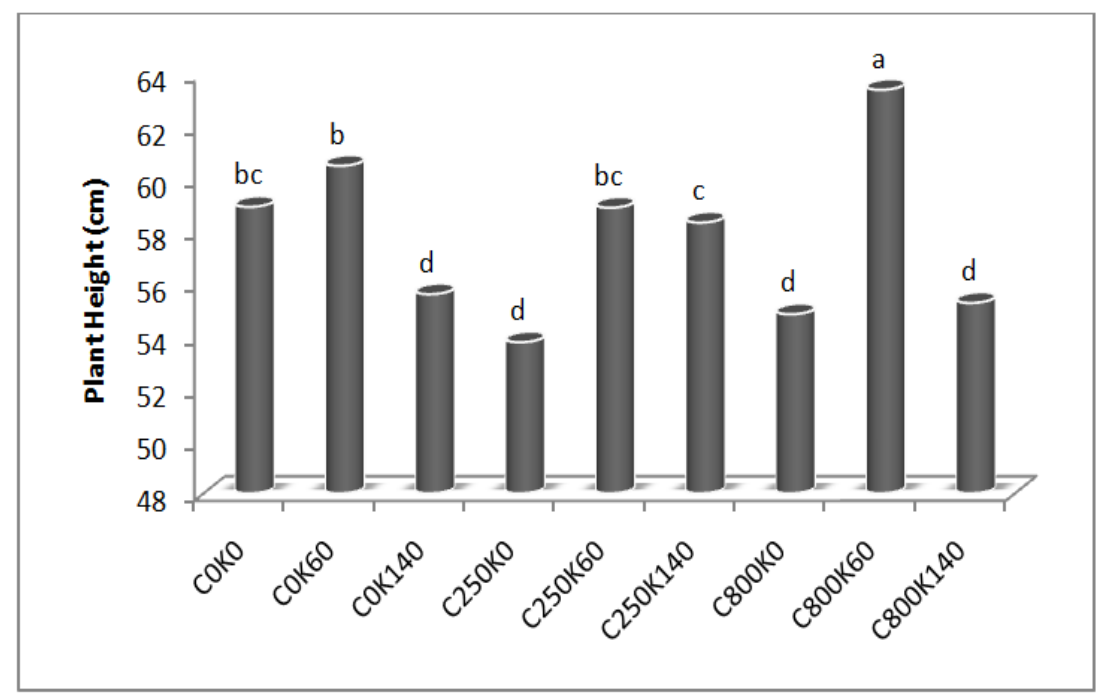

Fig. (2): Effect of charcoal and potassium and their interaction on plant height $(\mathrm{cm})$.

The importance of interaction between charcoal and potassium fertilizer was also found on technical stem length (Figure 3). The longest technical stem length was recorded in both control and interaction treatments charcoal and potassium at the rate of $\left(800 \mathrm{~g} / \mathrm{m}^{2}\right.$ and $\left.60 \mathrm{~kg} / \mathrm{ha}\right)$ respectively, which was $46.3 \mathrm{~cm}$. Despite the fact that thetechnical stem length was $45.5 \mathrm{~cm}$ when potassium was added alone at the rate of $60 \mathrm{~kg} / \mathrm{ha}$, so this value reduced with charcoal alone $250 \mathrm{~g} / \mathrm{m}^{2}$ to $40.9 \mathrm{~cm}$. These outcomes showed the impact of charcoal on plant ability to uptake potassium and other nutrients in the soil. Similar results were recorded by (Bakry et al., 2014 and Bakry et al., 2015).

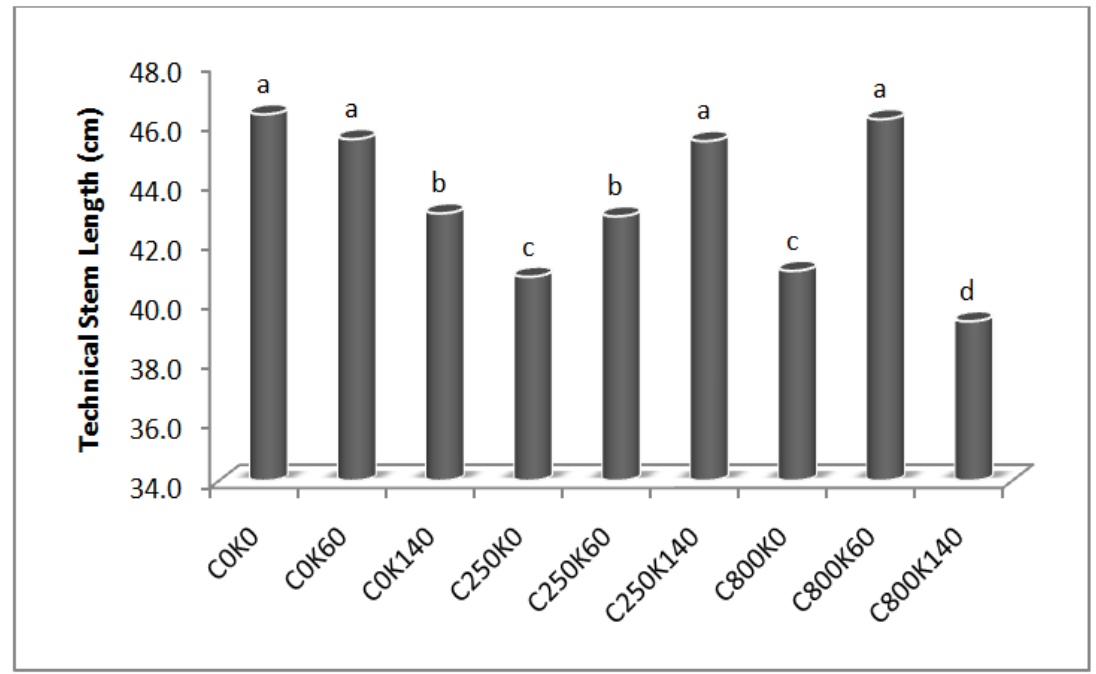

Fig. (3): Effect of charcoal and potassium and their interaction on technical stem length $(\mathrm{cm})$.

The greatest value of number of fruit branches/plant and number of capsules/plant were recorded in both of charcoal and potassium treatments at the rate of $\left(250 \mathrm{~g} / \mathrm{m}^{2}\right.$ and $60 \mathrm{~kg} / \mathrm{ha})$ and $\quad\left(250 \mathrm{~g} / \mathrm{m}^{2}\right.$ and $\left.140 \mathrm{~kg} / \mathrm{ha}\right)$, respectively (Figures 4 and 5). These results are in agreement with the results of (Shaaban and Abou El-Nour, 2012) who reported that the number of shoots and capsules/plant of flax were effected signifecantelly by adding $\mathrm{K}_{2} \mathrm{SO}_{4}$.Also, the current study is supported by Faloye et al. (2017) who reached to the fact that the combined application of fertilizer and biochar improved the crop development better than when applied individually. 


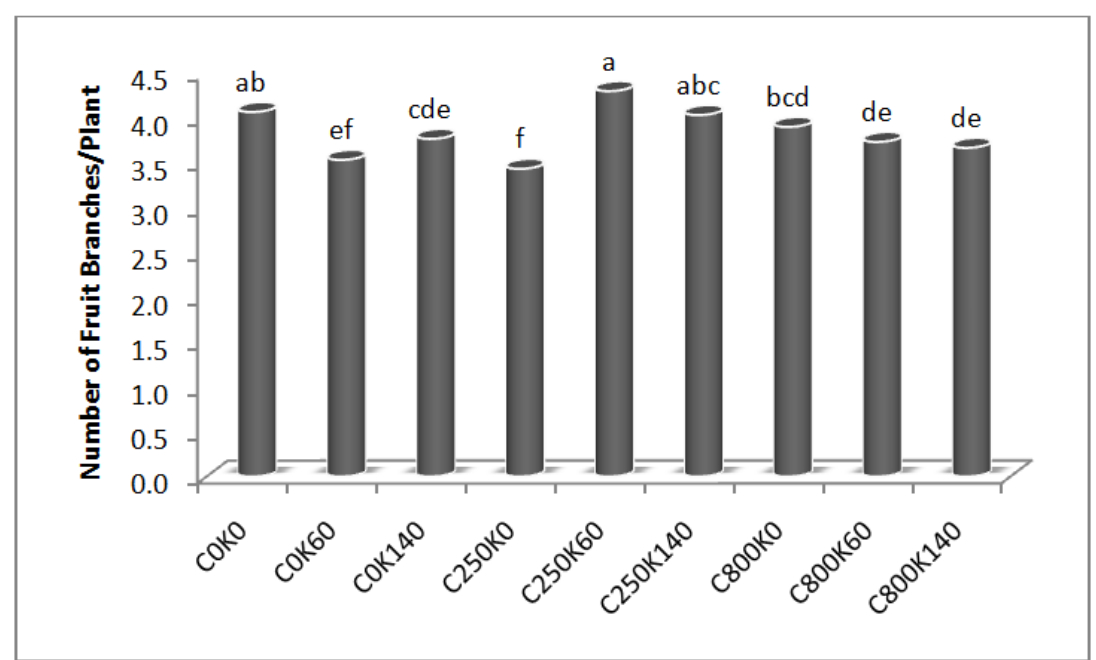

Fig. (4): Effect of charcoal and potassium and their interaction on number of fruit branches/plant.

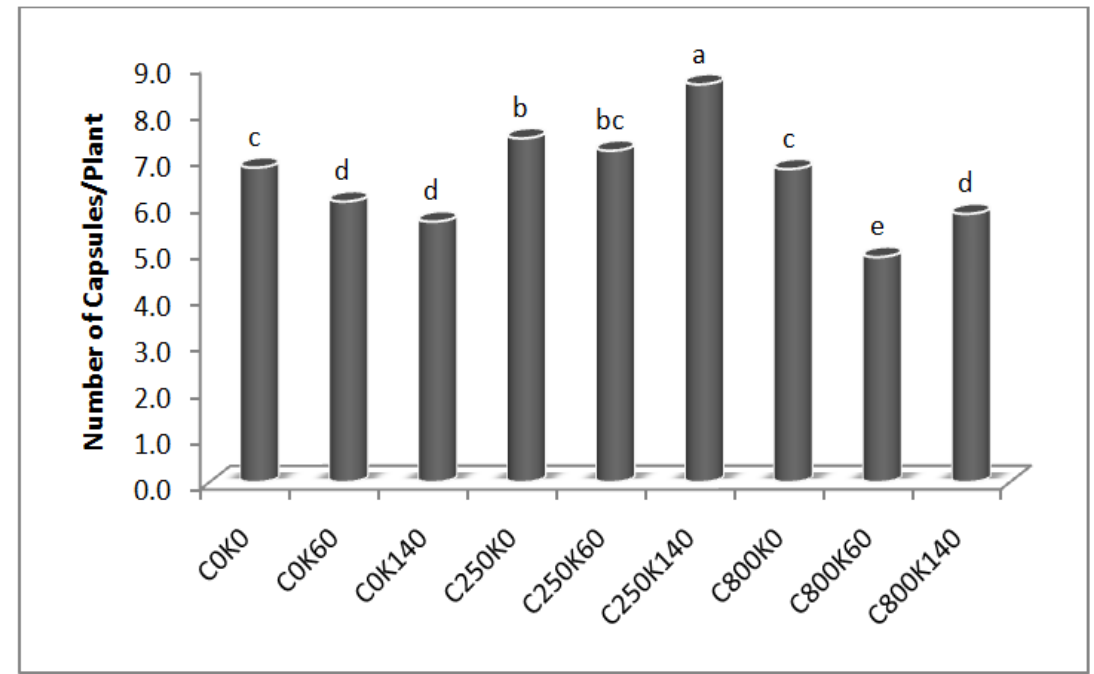

Fig. (5): Effect of charcoal and potassium and their interaction on number of capsules/plant.

Number of seeds/capsule was increased with adding charcoal at the rate of $250 \mathrm{~g} / \mathrm{m}^{2}$ which was about (8.8 seeds/capsule), (Figure 6). Additionally, potassium alone at the rate of $140 \mathrm{~kg} / \mathrm{ha}$ and charcoal with potassium at the rate of $\left(800 \mathrm{~g} / \mathrm{m}^{2}\right.$ and $\left.60 \mathrm{~kg} / \mathrm{ha}\right)$ produced approximately 8.7 seeds/capsule which was too close to the best result or endpoint according to the results from this study because,increasing fertilizer dose of N:P:K significantly increased number of seeds/capsule (Gupta et al., 2017). 


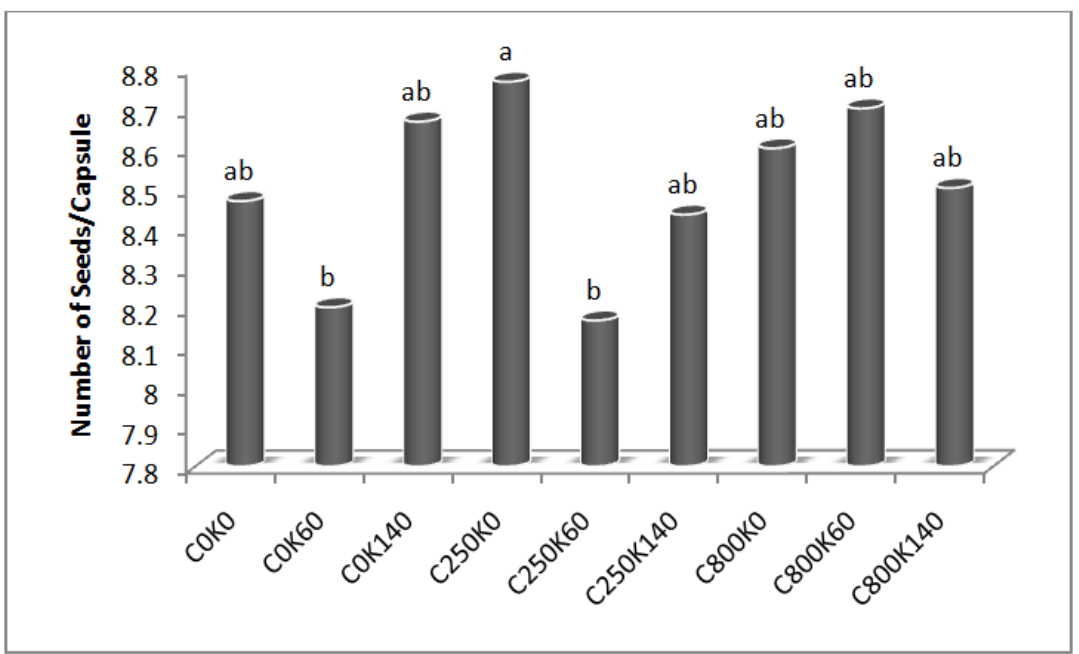

Fig.(6): Effect of charcoal and potassium and their interaction on number of seeds/capsule.

Stem diameter was also significantly increased by potassium and charcoal addition and their interaction. In the control treatment the value of the stem diameter was only about (1.6mm), while this result improved with adding potassium at the rate of $(60 \mathrm{~kg} / \mathrm{ha})$, and charcoal with potassium $\left(250 \mathrm{~g} / \mathrm{m}^{2}\right.$ and $\left.140 \mathrm{~kg} / \mathrm{ha}\right)$ which was about (1.8mm) (Figure 7).

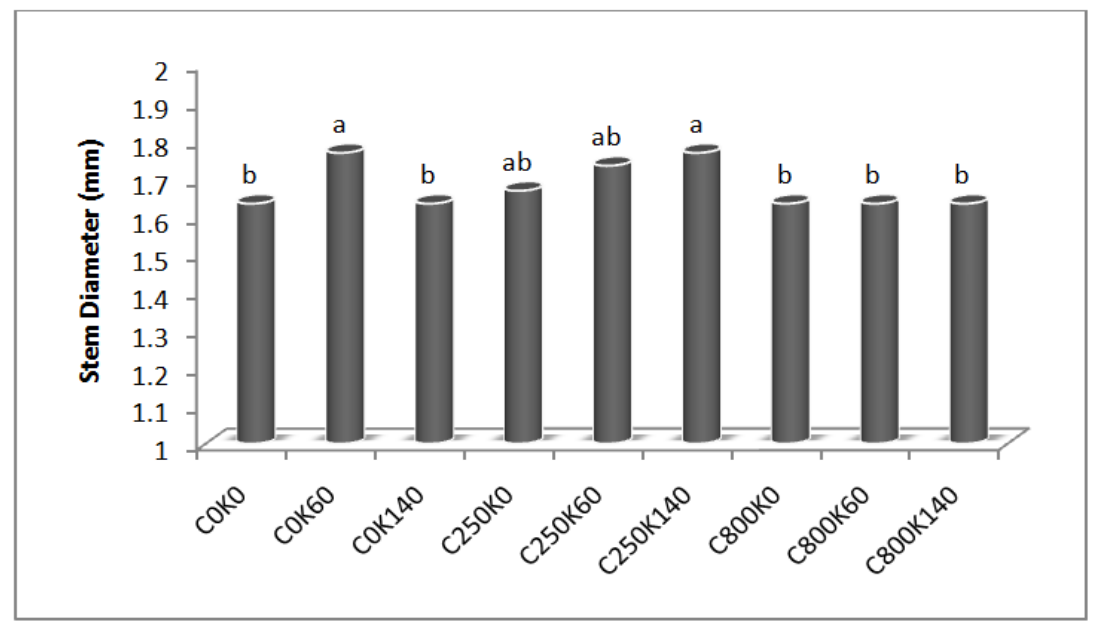

Fig. (7): Effect of charcoal and potassium and their interaction on stem diameter (mm).

Total fresh yield and dry stem yield were the parameters which relationship to fiber yield or straw yield determined during this current study (Figures 8 and 9). In the control treatment the value of the total fresh yield and dry stem yield were about (10.8 and $2.8 \mathrm{t} / \mathrm{ha})$, respectively. While, these results improved with adding potassium at the rate of $(60 \mathrm{~kg} / \mathrm{ha})$, which were approximately (11.3 and $3.3 \mathrm{t} / \mathrm{ha}$ ), respectively. Potassium fertilizer has an impact role to improve not only the yield but also the quality. These results were in agreement with (Salih et al., 2014a; Salih et al., 2014b; Salih et al., 2014c; Salih et al., 2015; Salih, 2015; and Salih et al., 2016). 


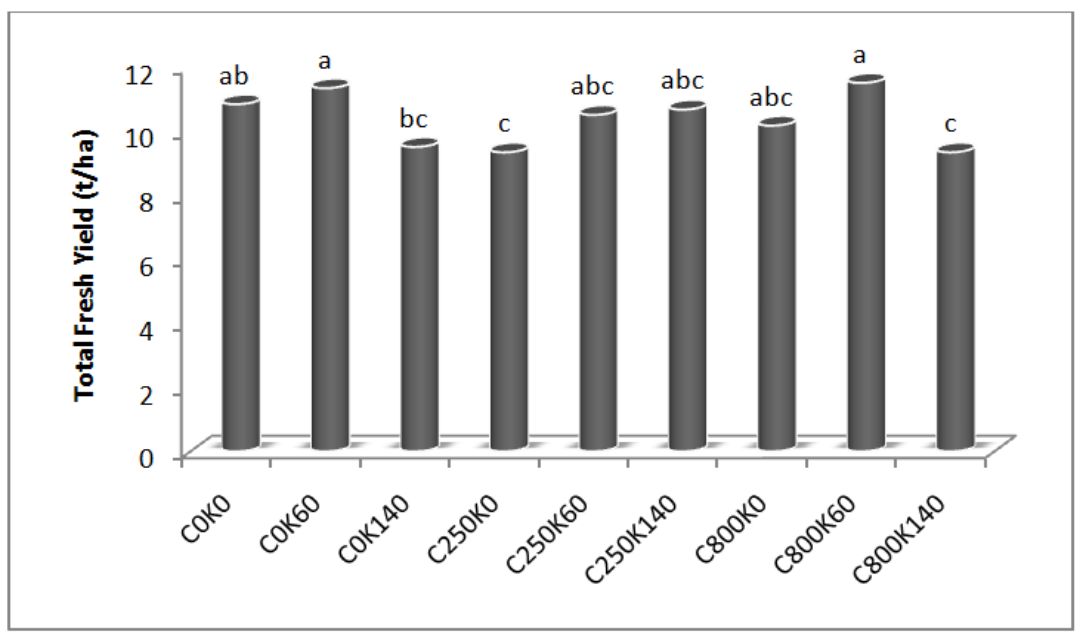

Fig. (8): Effect of charcoal and potassium and their interaction on total fresh yield ( $t / h a)$.

Interaction among charcoal and potassium also significantly increased yield parameters. As mentioned earlier, charcoal may caused to improve soil chemical, biological, and physical properties and plant ability to uptake nutrients, thus improve crop production. similar fact about affecting of charcoal and fertilizers on soil and plant were stated by (Steiner et al., 2007). The greatest value of the total fresh yield and dry stem yield were recorded when charcoal and potassium added at the rate of $\left(800 \mathrm{~g} / \mathrm{m}^{2}\right.$ and $60 \mathrm{~kg} / \mathrm{ha})$, respectively which was about (11.5 and $3.5 \quad \mathrm{t} / \mathrm{ha}$ ), respectively.

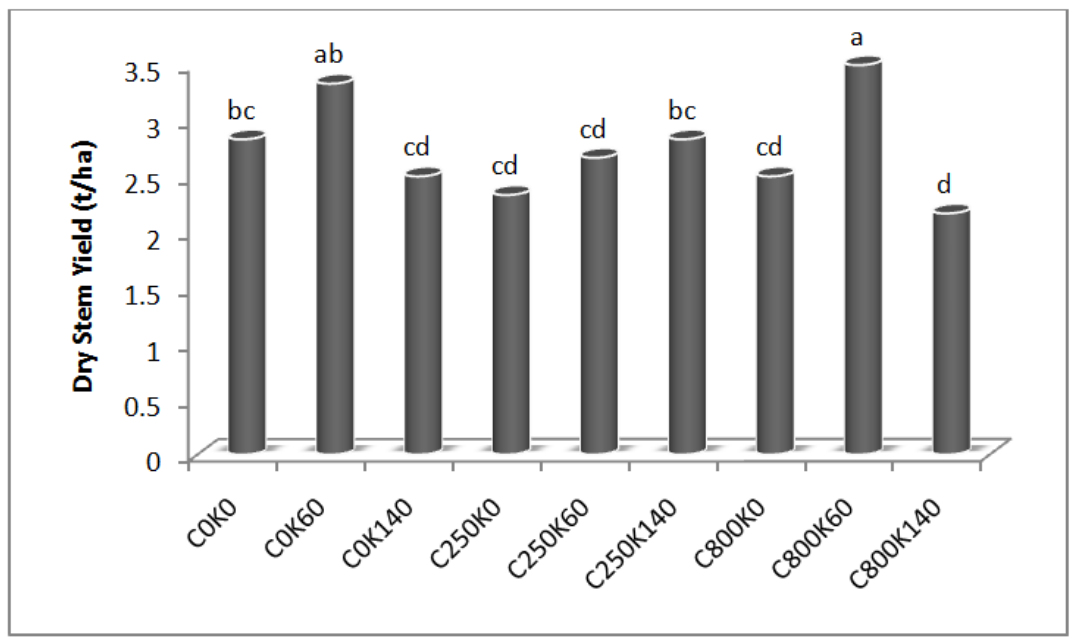

Fig. (9): Effect of charcoal and potassium and their interaction on dry stem yield ( $\mathrm{t} / \mathrm{ha}$ ).

\section{CONCLUSIONS}

The current study is strongly indicating the importance of including charcoal and potassium application in improving the growth and productivity of flax. The results directly confirm the role of charcoal, potassium, and their interaction on the parameters were studied.

Finally, future research must be focused on testing different sources and types and amount and size of charcoal, to obtain the right effect of charcoal on quantity and quality of plant production.

\section{ACKNOWLEDGMENTS}

Authors would like to thanks the all staffs at the researching filed, the Field of Grdarasha, College of Agricultural Engineering Sciences, 
Salahaddin University - Erbil for preparing the field and equipments during the research. Also, authors want to thanks to Assist Prof. Bahar Jalal Mahmood to give the seeds of flax were used during this research.

\section{REFERENCES}

Bakry, A. B. , Ibrahim, O. , Eid, A. and Badr, E. (2014). Effect of Humic Acid, Mycorrhiza Inoculation, and Biochar on Yield and Water Use Efficiency of Flax under Newly Reclaimed Sandy Soil. Agricultural Sciences, $\mathbf{5}$, 1427-1432. doi: $10.4236 /$ as.2014.514153

Bakry, A. B. , Nofal, O. , Zeidan, M. and Hozayn, M. (2015) Potassium and Zinc in Relation to Improve Flax Varieties Yield and Yield Components as Grown under Sandy Soil Conditions. Agricultural Sciences, 6, 152-158. doi: 10.4236/as.2015.61013.

Faloyea, O.T., Alatisea, M.O., Ajayia, A.E., and Ewulob, B.S. (2017). Synergistic effects of biochar and inorganic fertiliser on maize (zea mays) yield in an alfisol under drip irrigation. Soil \& Tillage Research, 174, 214-220.

Gale, N. V., M. A. Halim, M. Horsburgh, and S. C. Thomas. (2017). Comparative responses of early-successional plants to charcoal soil amendments. Ecosphere 8(10):e01933. 10.1002/ecs2.1933.

Glaser, B., Lehmann, J. \& Zech, W. (2002). Ameliorating physical and chemical properties of highly weathered soils in the tropics with charcoal - a review. Biol Fertil Soils 35: 219. https://doi.org/10.1007/s00374-002-0466-4

Gupta, M., Kour, S., and Gupta, V. (2017). Effect of Different Doses of Fertilizers on Yield and NPK Uptake Of Linseed (Linum Usitatissimum L.). Bangladesh J. Bot. 46(2): 575-581.

Khalifa, R. Kh. M.; Manal F. M.; Bakry A. B. and Zeidan M. S. (2011). Response of some flax varieties to micronutrients foliar application under newly reclaimed sandy soil. Australian Journal of Basic and Applied Science, 5(8): 1328-1334.

Khourang, M; Parissa B. and Reza O. (2012). Effect of some chemical and biological fertilizer on productivity of a medicinal flax (Linum usitatssimum L.) plant. International Journal of Agronomy and Plant Production 3(3): 78-83.

Kingshuk, R., Sadao N., and Shigeo S. (2012). Effects of Charcoal-treated Soils on Plant Growth and Nutrient Leaching. Papers on Environmental Information Science, Vol.32 (The 32th Conference on Environmental Information Science).

Malisa, M.N., Hamdan, J., and Husni, M.H.A. (2011). Yield Response of Kenaf (Hibiscus cannabinus L.) to Different Rates of Charcoal and Nitrogen Fertilizer on Bris Soils in Malaysia. Middle-East Journal of Scientific Research 10 (1): 54-59

Martin, J. H.; Richard P. W. and David L. S. (2006). Principles of field crop production. $4^{\text {th }}$ edition, New Jersey Columbus, Ohio.

Salih, R.F., Abdan, K. and Wayayok, A. (2014a). Growth Responses of Two Kenaf Varieties (Hibiscus cannabinus L.) Applied by Different Levels of Potassium, Boron and Zinc. Journal of Agricultural Science, 6 (9), 37-45.

Salih, R.F., Abdan, K., Wayayok, A., and Hashim, N. (2014b). Effect of Potassium, Boron and Zinc on Nitrogen Content in Bast and Core Fibres for Two Kenaf Varieties (Hibiscus cannabinus L.). International Journal of Development Research, 4(12): 2581-2586.

Salih, R.F., Abdan, K., Wayayok, A., Rahim, A. A., and Hashim, N. (2014c). Response of Nitrogen Content for Some Varieties of Kenaf Fiber (Hibiscus cannabinus L.) by Applying Different Levels of Potassium, Boron and Zinc. Agriculture and Agricultural Science Procedia, 1(2):375-80.

Salih, R.F., Abdan, K., Wayayok, A., and Hashim, N. (2015). Improvement of Morphological Properties of Kenaf (Hibiscus cannabinus L.) by Adding Nutrients. ICSAFEI-178", 7th International Conference on Sustainable Agriculture for Food,Energy and Industry in Regional and Global Context, ICSAFEI2015”.

Salih, R.F. (2015). Improve Protein Content in the Cell Wall of the Kenaf Fibers. LAP LAMBERT Academic Publishing. Germany.

Salih, R.F., Abdan, K., Wayayok, A., Hashim, N., \& Rahman, K. A. (2016). Improve Quality and Quantity of Plant Products by Applying 
Potassium Nutrient (A Critical Review). Journal of ZankoySulaimani, 18(2),197-208.

Shaaban, S. H. A. and Abou El-Nour, E. A. A. (2012). Effect of Different Potassium Sources on Yield and Nutrient Uptake by Flax (Linum usitatissimum L.) Grown on Loamy Sand Soil. Journal of Applied Sciences Research, 8(3): 1425-1429.

Steiner, C., Teixeira, W.G., Lehmann, J. et al. (2007). Long term eVects of manure, charcoal and mineral fertilization on crop production and fertility on a highly weathered Central Amazonian upland soil. Plant Soil. 291: 275. https://doi.org/10.1007/s11104$\underline{007-9193-9}$

Oguntunde, P.G., Fosu, M., Ajayi, A.E. et al. (2004). Effects of charcoal production on maize yield, chemical properties and texture of soil. Biol Fertil Soils 39: 295. https://doi.org/10.1007/s00374-003-0707-1

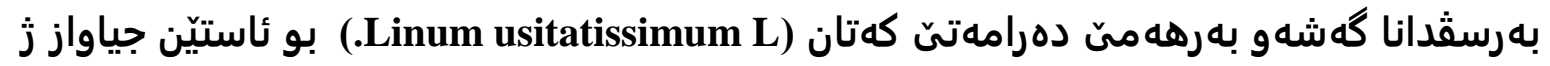

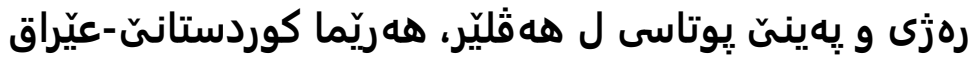

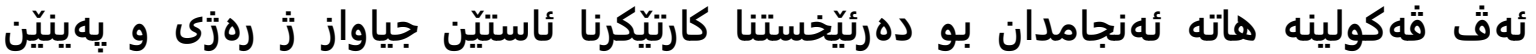

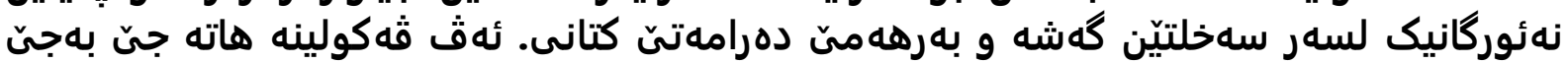

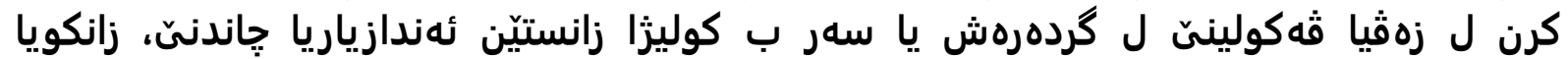

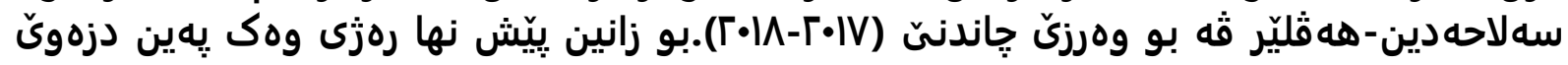

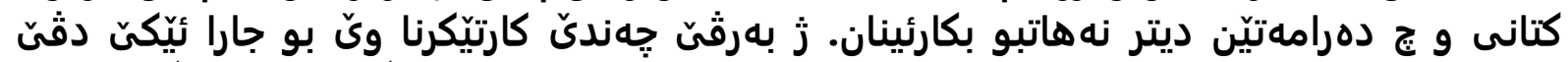

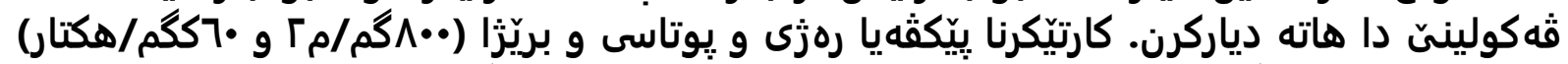

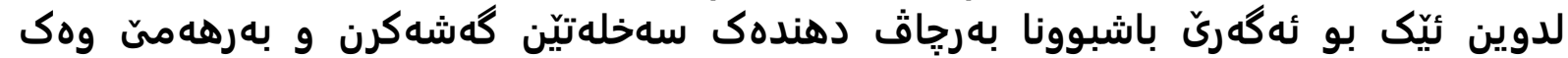

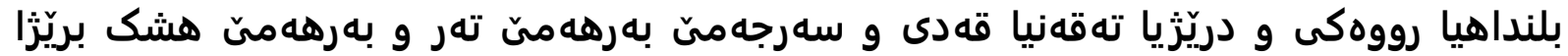

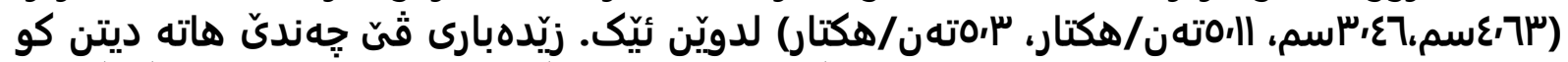

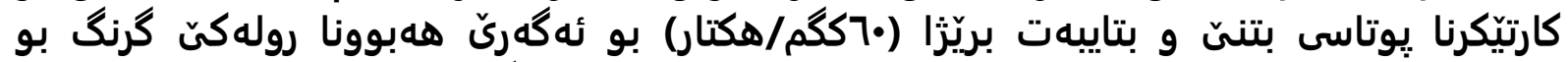

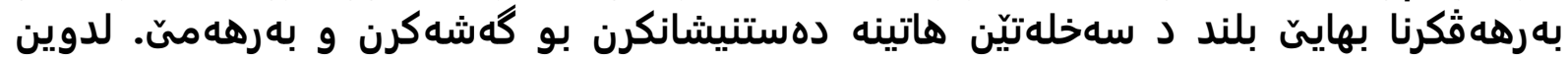

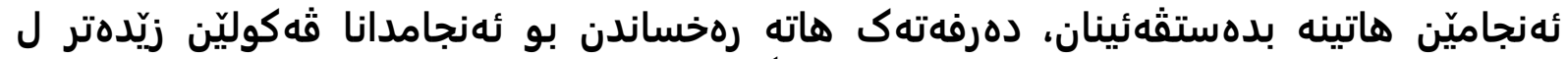

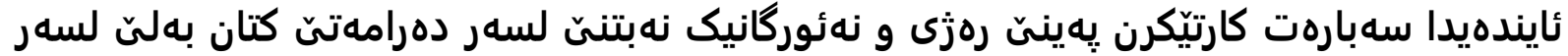
دهرامهتيّن ديتر زَى.

استجابة نمو والحاصل الكتان (Linum usitatissimum L.) لمستويات مختلفة من الفحم والأسمدة البوتاسية في أربيل ، إقليم كردستان - العراق 
الخلاصة

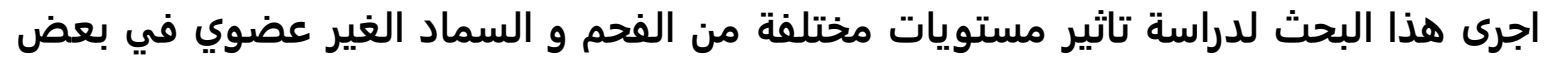

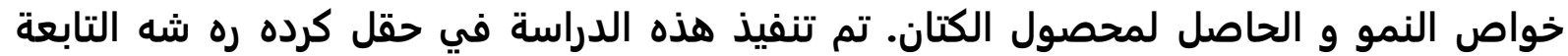

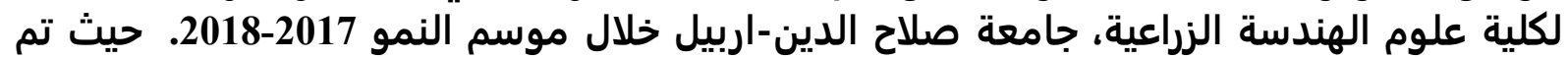

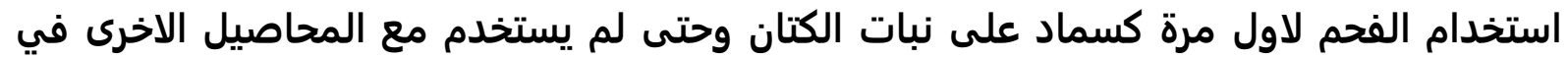

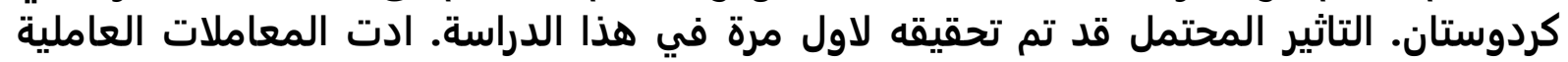

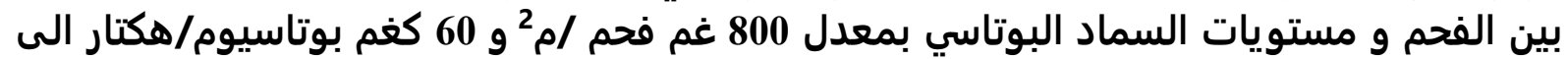

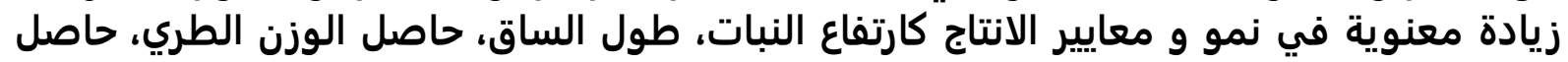

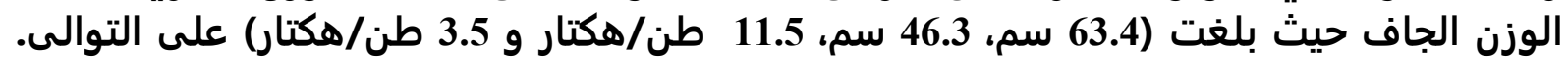

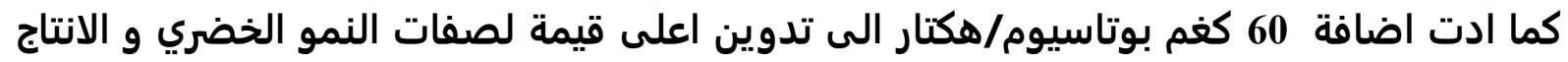

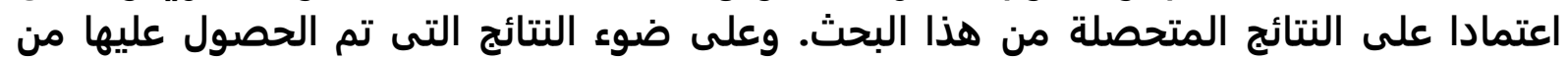

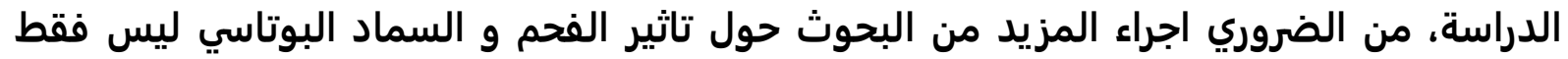
على محصول الكتان وانما على المحري المريل المزيد من الاخوى. 